\title{
The Effect of Dependency on Repurchase Intention and Technostress
}

\author{
Antonius Satria Hadi \\ Department of Entrepreneurship, Universitas Widya Mataram, Indonesia \\ Author correspondence: suns.sund@gmail.com
}

\begin{abstract}
This study aims to investigate the effect of convenience to dependency toward smartphone, the effect of social need to dependency toward smartphone, the effect of social influence to dependency toward smartphone, the effect of dependency toward smartphone on repurchase intention, and the effect of dependency toward smartphone on technostress. This research have five hypotheses. Data were collected from 170 respondents which got from questionnaire distributed to graduate degree students of Universitas Gadjah Mada, Yogyakarta. Based of the data collection, this analysis using structural equation modeling technique with software LISREL 8.72. The results of this research showed that convenience, social need, and social influence have positive and significant effects to dependency, while the dependency have positive and significant effects to repurchase intention and technostress. All (five) hypotheses on this research have been accepted. Each of those hypotheses discussed in detail through this article.
\end{abstract}

Keywords: Convenience, dependency, media dependency theory, repurchase intention, smartphone, social influence, social need, technostress.

\begin{abstract}
Abstrak: Penelitian ini bertujuan untuk mengetahui pengaruh kenyamanan terhadap ketergantungan smartphone, pengaruh kebutuhan sosial terhadap ketergantungan smartphone, pengaruh sosial terhadap ketergantungan smartphone, pengaruh ketergantungan smartphone terhadap minat beli ulang, dan pengaruh ketergantungan smartphone pada technostress. Penelitian ini memiliki lima hipotesis. Data dikumpulkan dari 170 responden yang diperoleh dari kuesioner yang dibagikan kepada mahasiswa pascasarjana Universitas Gadjah Mada, Yogyakarta. Berdasarkan pengumpulan data, analisis ini menggunakan teknik pemodelan persamaan struktural dengan software LISREL 8.72. Hasil penelitian ini menunjukkan bahwa kenyamanan, kebutuhan sosial, dan pengaruh sosial memiliki pengaruh positif dan signifikan terhadap ketergantungan smartphone, sedangkan ketergantungan smartphone memiliki efek positif dan signifikan terhadap minat beli ulang dan teknostress. Kelima hipotesis pada penelitian ini dapat diterima. Masing-masing hipotesis dibahas secara rinci melalui artikel ini.
\end{abstract}




\section{BACKGROUND}

Smartphone is a phone that have more advanced technology, more features, and more attractive appearance than ordinary phones. This statement is supported by the opinion of Backer (2010) that smartphone is a phone that bring together leading capabilities function like a computer by offering features, such as a personal digital assistants (PDAs), an internet access, an email, and a Global Positioning System (GPS). Smartphone are no longer a sophisticated tool of communication, but nowadays a necessity in people's lives. For smartphone users, their smartphone are the first thing they see in the morning and the last thing they see before going to bed (Ting et al., 2018).

Figure 1 shows that the use of smartphone increase starting in 2013, which only amounted to 27.4 million users to 103 million users in 2018 in Indonesia. It can be said that the duration of contact between users and smartphone or the duration of the use of smartphone by users (consumers) spend hours, and tend to be relatively long everyday, anywhere, and anytime.

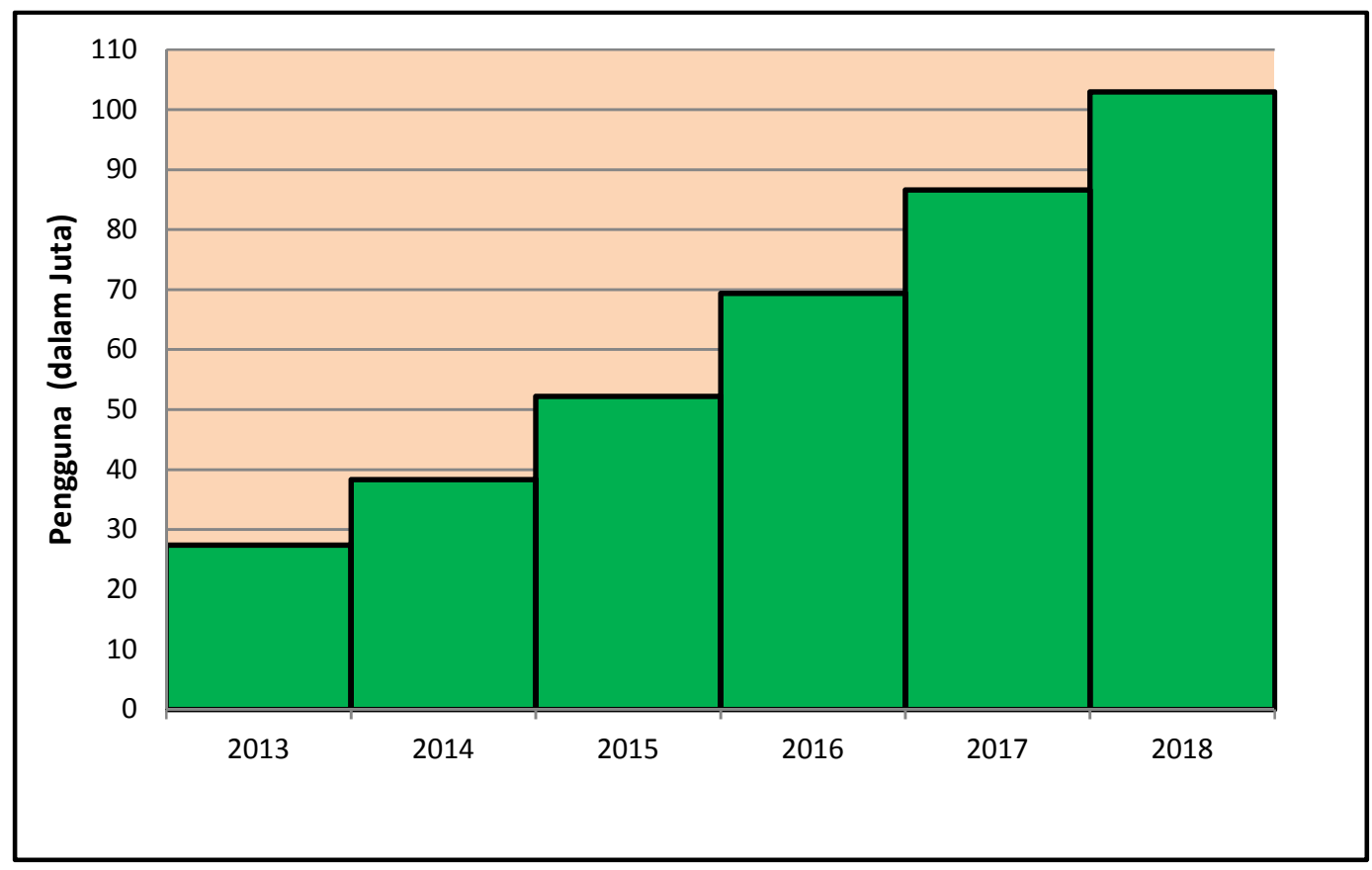

Source: https://id.techinasia.com/jumlah-pengguna-smartphone-di-indonesia-2018/

Figure 1. Number of Smartphone Users in Indonesia

A person's behavior that reflects very dependence toward smartphone is caused by their daily activities tend to be spent on using their smartphone, and smartphone is always brought in anywhere and anytime. This statement is reinforced by the opinion of BallRokeach and DeFleur (1989) who argue that the more often a person depends on the need for a media, the more important the role of the media in person's life, and the theory identifies how people use and become dependent on the media.

The first factor that can cause dependency toward smartphone is convenience. Convenience is illustrated simply as a pleasant feeling when someone using an item (in this case is a smartphone). This is in accordance with the opinion expressed by Davis et 
al., (1989) which states that comfort is the extent to which an individual receives an impact after using technology to be pleasant in itself, regardless of the consequences of anticipated performance. The second factor that affects consumer dependency toward smartphone is social need. Social need is a person's need to interact, communicate, and still want to connect with others (Tikkanen, 2009). The third factor that influences dependency toward smartphone is social influence. The social influence is the way others influence a person's beliefs, feelings, and behaviors (Mason et al., 2007).

Dependency toward smartphone is influenced by several factors, such as convenience, social need, and social influence tends to have an impact on the appearance of repurchase intention. The intention to repurchase is the intention of consumers to repurchase the same product caused by positive experience after purchasing or when consuming the product. This is consistent with the opinion of Thamrin (2003) which states that a high repurchase intention reflects a high level of satisfaction from consumers when deciding to consume the product again.

Dependency toward smartphone tends to trigger the emergence of repurchase intention from its users. This opinion is supported by the results of a research by Mafe and Blas (2006) which found that consumers with a high level of dependency toward smartphone positively correlated with consumer behavior of future purchases.

The impact of a person's dependency toward smartphone in addition to repurchase intention is a positive impact in the lives of users in the form of fast data access, access to entertainment, even instant and intensive communication with other people can be obtained quickly (Mayasari, 2010). Other impacts caused by these dependency behaviors tend to be negative which include consumptive behavior, anxiety when not carrying their smartphone, disturbed sleep patterns, reduced direct physical contact with others, and so on (Rice-Lincoln, 2011).

Another impact caused by excessive dependency towards person's smartphone in the form of stress suffered or experienced by individuals due to technology, the term is called technostress (Shu et al., 2008). This is supported by the results of a study by Lee et al., (2014) which found that the use or compulsive behavior that represented excessive dependency toward smartphone had a positive and significant effect on technostress. This means that the higher the excessive dependency (compulsive use) of someone on their smartphone, the higher the technostress experienced or suffered by that person, and vice versa.

Based on the results of previous studies it can be seen that there is an empirical research gap that is research that proves the influence of convenience, social need, social influence on the dependency towards smartphone that affect repurchase intention and technostress together has never been done, so the researcher intends to test it in this research.

Another thing that became the focus of this research was contextual research. The majority of previous research is related to dependency on radio (Ball-Rockeach, 1985; 1989; 1998; Loges, 1994), television (Ball-Rockeach, 1985; 1989 1998; Loges, 1994), and the internet (Patwardhan \& Yang, 2003; Mafe \& Blas, 2006; Alcañiz et al., 2008). There is a gap in the context of research that is still very little research that takes the context of dependency toward smartphone, so the context in this study is focused on dependency towards smartphone. 
In addition, this research also attempts to fill the theoretical and practical gap that in this study is able to verify, confirm, and strengthen the Individual Media Dependency Theory which is also still minimal conducted in Indonesia. It is closely related to the methodological gap which means that this study will test the measuring instrument of dependency carried out in different countries (Indonesia), so that cross-country validation can be fulfilled. Thus, this study seeks to fill the empirical, contextual, theoretical, practical, and methodological research gaps that described above.

\section{CONCEPTUALIZATION AND HYPOTHESES}

\section{Media Dependency Theory}

Media dependency can be measured based on media dependency theory. Media dependency theory predicts that a person relies on media information to meet certain needs and achieve certain goals (Ball-Rokeach, 1998). Dependency can be said to be the behavior of consuming or using certain goods/services carried out by someone who tends to overdo it anywhere and anytime continuously.

This means that someone who experiences dependency tends not to be physically separated from the goods and services used anywhere and anytime. For example, a person who is dependent toward a smartphone tends to spend most of his/her daily activities on the smartphone, and the person tends not to do other daily activities properly (ignored).

A person's behavior that reflects highly dependent toward a smartphone is that smartphones are always brought anywhere, anytime, even when the person wants to sleep at night. If it happens continuously to someone, it will have a negative impact on the individual's psychological conditions. For example, an individual who is using a smartphone, but suddenly the smartphone is damaged, then the person spontaneously feels confused and exaggerated, or even to experience the stress of the incident.

The statement about dependency theory above is in accordance with the opinion of Ball-Rokeach and DeFleur (1989) which suggests that the more often a person depends on the need for a media, the more important the role of the media in person's life and the theory identifies how people use and become dependent on the media.

\section{Media Dependency at Micro Level}

Media dependency theory which at the micro level, is individual media dependency. Individual media dependency is defined as a relationship that places an individual's capacity to achieve his goals depending on a particular way, namely access to mediacontrolled information resources (Ball-Rokeach et al., 1985). It shows how important certain media to individuals, because individuals tend to achieve their goals and desires when using certain media. This means that individuals must depend on certain media in order to fulfill their objectives. If it is not dependent on certain media, the goal will not be achieved, so this theory provides a real basis for measuring individual dependency relationships related to certain media (Grant et al., 1991; Loges, 1994).

The realization of media dependency at the micro level as explained above reveals how important the role of certain media is to create dependency behavior. One particular type of media that can cause dependency is a smartphone. Smartphone are the most sophisticated mobile phones at this time, one of which functions as a medium/communication tool. 


\section{The Effect of Convenience to the Dependency toward Smartphone}

Consumers can obtain useful information easily and quickly through the internet on their smartphone, check an e-mail, and use a chat facilities on the network (Genova, 2010; Hudson, 2010). The consumer's convenience is derived from the fusing of ordinary phones and laptops into smartphone (Stephen and Davis, 2009). Consumers who are comfortable when using and after using their smartphone tend to repeat the same activities anywhere and anytime (Hahn, 2010). The dependency is a certain activity that is carried out repeatedly (Hovart, 1989). The more comfortable someone when using and after using his/her smartphone, the person tends to be more dependent on his/her smartphone. Thus the first hypotheses is:

$\mathrm{H}_{1}$ : The convenience of smartphone has a positive effect on consumers' dependency toward a smartphone.

\section{The Effect of Social Needs to the Dependency toward Smartphone}

Social needs include the desire to be loved, partnership, friendship, and accepted by others (Schiffman, et. al., 2009). Smartphones have become much more flexible, allowing consumers to increase their use to communicate, and maintain the relationship between individuals (Lippincott, 2010). A consumer social need can be fulfilled through the features of smartphone (Raskin, 2006). The higher a person's social needs (consumers), the higher his/her dependency toward smartphone (Suki \& Suki, 2013; Wei and Lo's, 2006). This means that the higher the social needs of a person (consumer), the higher the dependency toward a smartphone, on the contrary if the social needs of a person (consumers) are lower, then the dependency toward smartphones is also lower. Thus the second hypotheses is:

$\mathrm{H}_{2}$ : Consumers' social need have a positive effect on consumers' dependency toward a smartphone.

\section{The Effect of Social Influences to the Dependency toward Smartphone}

A social influence is a way for others to influence a person's beliefs, feelings, and behaviors, so that there are changes in attitudes or behaviors, as a result of interaction with others (Mason et al., 2007). A social influence is often regarded as a powerful influence through observation, perception, or anticipation of decisions made by others which affect the dependence of consumers (users) on smartphones (Auter, 2007; Suki \& Suki, 2013). Friends and family members are seen as social influencers who are considered important for consumers in encouraging greater dependency toward smartphones. It shows that other parties who give a very strong social influence to someone until he experiences dependency toward his/her smartphones are usually people who have known their characters in depth such as close friends or even relatives such as parents (father or mother), brother, and sister. This means that the higher the social influence of the other parties, the higher the tendency of dependency toward smartphones. Conversely, if the needs of social influence from other parties are lower, then the dependency toward smartphones tends to be lower (Ting et al., 2011; Klobas and Clyde, 2001). Thus the third hypotheses is:

$\mathrm{H}_{3}$ : Social influence has a positive effect on consumers' dependency toward a smartphone. 


\section{The Effect of the Dependency towards Smartphone on Repurchase Intention}

The dependency is a condition tied to very strong habits and so that addictive behavior appears on something (Wulandari, 2015). Based on this description, the dependency can be interpreted as a condition in which individuals feel addicted to something that is liked on various occasions, resulting in a lack of control over behavior. A smartphone as a necessity and have a strong tendency for high usage continuously, which is bound and do not want to be separated (Tian et. al., 2009). Consumers not only have personal knowledge about attributes, but also have positive personal experiences about how smartphones are able to meet consumer needs (Keaveney and Parthasarathy, 2001). Oliver (1999) states that the response caused by past positive experiences received to make purchases repeatedly is called repurchase intention. By this explanation, it can be said that repurchase intention is the tendency of consumer buying behavior on an item or service that is carried out repeatedly over a certain period of time and actively likes and has a positive attitude towards an item or service, based on past experiences. Some research results found that the dependency toward smartphone had a positive and significant effect on repurchase intention (Suki \& Suki, 2013; Ting et. al., 2011; Vahabzadeh et. al., 2014). Thus the fourth hypotheses is:

$\mathrm{H}_{4}$ : Consumers' dependency toward smartphone has a positive effect on consumers' repurchase intention.

\section{The Effect of the Dependency toward Smartphone on Technostress}

Griffiths (1998) states that the dependency is an aspect of compulsive behavior. Activities that direct individuals to engage in repeated actions (O'Guinn and Faber, 1989). Excessive compulsive/dependent behavior can result in the emergence of adverse consequences in the form of psychological stresses, such as depression and stress (Matusik \& Mickel, 2011). The ability of smartphones that are able to convey feedback and communication quickly causes users to check their smartphones more often and are considered as compulsive behavior (Oulasvirta et.al., 2012). Users who experience stress due to information technology and excessive communication called technostress (Ayyagari et al., 2011). The use or compulsive behavior that represents dependency toward smartphone has a positive and significant effect on technostress (Lee, et.al., 2014). This means that the higher the excessive dependency (compulsive use) of someone on their smartphones, the higher the technostress experienced or suffered by that person, and vice versa. Based on the description of the relationship between the dependency on smartphones and technostress. Thus, the fifth hypotheses is:

$\mathrm{H}_{5}$ : Consumers' dependency toward smartphone has a positive effect on technostress.

The research model in Figure 2 below shows the relationship between the variables studied in this study and the hypotheses proposed. 


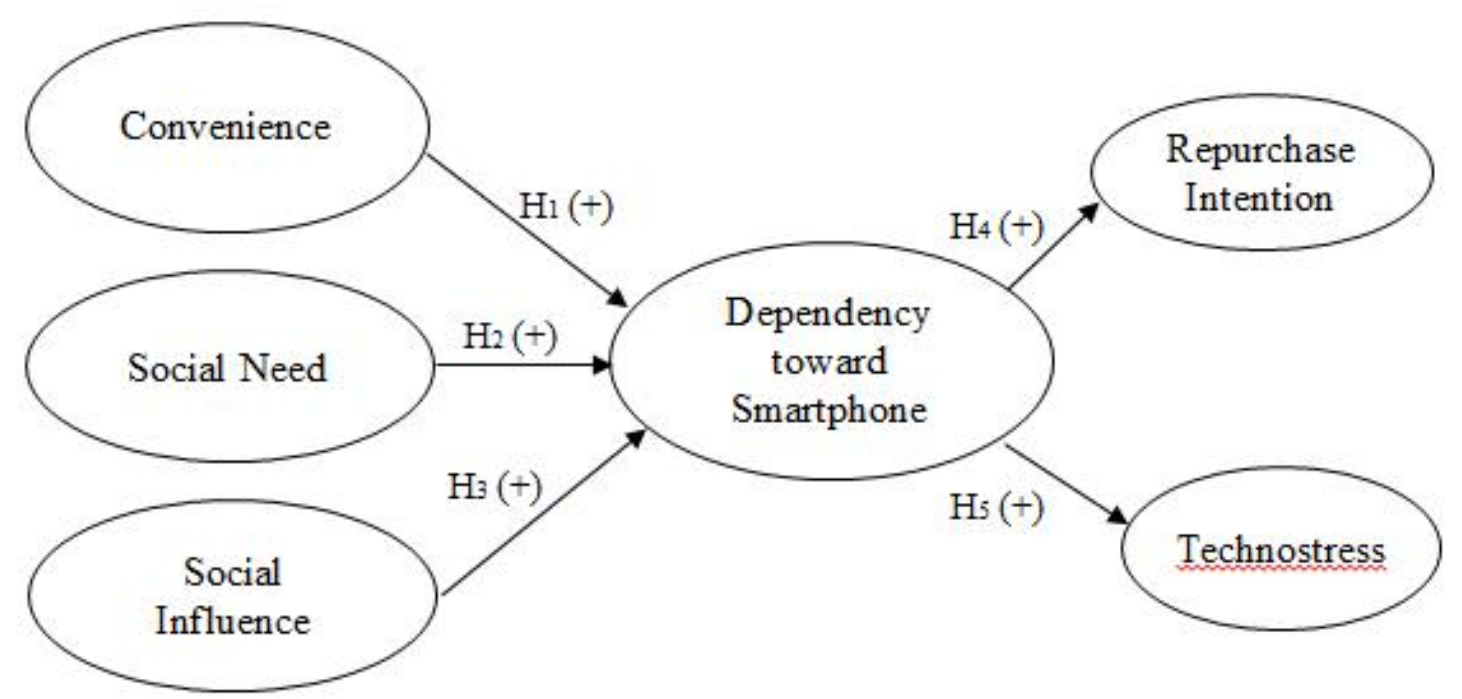

Figure 2. Research Model

\section{RESEARCH METHODS}

This research is a type of quantitative research in the form of hypotheses testing using a survey method and conducted on January 2016. Respondents in this study were 170 people. The sampling technique uses purposive sampling. The samples were active students of Universitas Gajah Mada who have smartphone and included in the category of younger adult aged 18-24 years old (Auter, 2007).

This research questionnaire was adapted from previous studies. Four variables in this research were adopted from Ting et. al. (2011). They are the convenience with five questions, the social needs with four questions, the social influence with four questions, and the dependency with four questions. The repurchase intention was adopted from Ting et. al. (2011) and Suki \& Suki (2013) with five questions. The technostress was adopted from Lee et. al. (2014) with four questions.

Validity testing using factor analysis or confirmatory factor analysis (CFA) with the varimax rotation method. An instrument in the form of a statement item is said to be valid if: a) loading factor has a value of $\geq 0,30$ (no cross loading); b) KMO value $>0.4$, and the significance value of Bartlett's test of Sphericity $<0.05$; c) eigenvalue of each loading component are more than 1 (Hair et. al., 2010). The validity testing uses SPSS software version 20.

Reliability testing in this study uses Cronbach's Alpha. Nunnaly (1978) revealed that the instrument was declared reliable, if the value of Corrected Item Total Correlation was $\geq 0,4$ and the value of Cronbach's Alpha $>0.70$. The data analysis method has been used to test the hypotheses in this study is SEM (Structural Equation Modeling) with LISREL 8.72 software. While the suitability measure is descriptively stated in the Goodness of Fit Index. The results of validity and reliability test are presented in Table 1 below. 


\section{RESULTS AND DISCUSSION}

Overall the total questionnaires distributed were 200 questionnaires. Thirty questionnaires to test the validity and reliability distributed to respondents. Then distributed 170 questionnaires through online with the applications from google (docs.google.com), then distributed 22 questionnaires link (http://goo.gl/forms/ $6 l C E y P N k R v)$. Furthermore, the distribution of questionnaires through offline is face-toface directly with respondents and collected 148 questionnaires. Based on the data collection, 56\% (96 people) respondents were women, and the remaining 44\% (74 people) were male respondents. Most of them are 21-24 years collected from 102 respondents $(60 \%)$, while the rest are respondents with ages between 18-20 years collected from 68 respondents $(40 \%)$. The majority of respondents stated that the duration of smartphone usage for 1-2 years was 59 respondents (35\%), usage time of 5-6 years was 58 respondents $(34 \%)$, and duration of 3-4 years was 53 respondents $(31 \%)$. The results of descriptive statistics are presented in the Table 2 below.

\section{Result of Instruments Testing}

Table 1. Construct Validity and Reliability

\begin{tabular}{|c|c|c|c|c|c|c|}
\hline \multirow[b]{4}{*}{ Variable } & \multicolumn{6}{|c|}{ Construct Validity } \\
\hline & \multicolumn{4}{|c|}{ Convergent Validity } & \multicolumn{2}{|c|}{ Discriminant Validity } \\
\hline & \multirow[b]{2}{*}{$\begin{array}{c}\text { Standardized } \\
\text { Loading Factor } \\
\geq \mathbf{0 , 5 0}\end{array}$} & \multirow[b]{2}{*}{$\begin{array}{c}A V E \\
\geq 0,50\end{array}$} & \multicolumn{2}{|c|}{ Construct Reliability } & \multirow[b]{2}{*}{$\begin{array}{c}\text { Rotated } \\
\text { Component } \\
\text { Matrix }\end{array}$} & \multirow[b]{2}{*}{$A V E>R^{2}$} \\
\hline & & & $\begin{array}{c}\text { Standardized } \\
\text { Cronbach's } \\
\text { Alpha } \\
\geq 0,7\end{array}$ & $\begin{array}{l}\text { Composite } \\
\text { Reliability } \\
\quad \text { (CR) } \\
\geq 0,7\end{array}$ & & \\
\hline Convenience & $\geq 0,50$ & 0,74 & 0,88 & 0,93 & no cross loading & Yes \\
\hline $\begin{array}{l}\text { Social } \\
\text { Needs] } \\
\backslash\end{array}$ & $\geq 0,50$ & 0,65 & 0,91 & 0,88 & no cross loading & Yes \\
\hline $\begin{array}{l}\text { Social } \\
\text { Influence }\end{array}$ & $\geq 0,50$ & 0,58 & 0,81 & 0,85 & no cross loading & Yes \\
\hline Dependency & $\geq 0,50$ & 0,47 & 0,86 & 0,78 & no cross loading & Yes \\
\hline $\begin{array}{l}\text { Repurchase } \\
\text { Intention }\end{array}$ & $\geq 0,50$ & 0,76 & 0,91 & 0,94 & no cross loading & Yes \\
\hline Technostress & $\geq 0,50$ & 0,74 & 0,89 & 0,92 & no cross loading & Yes \\
\hline \multirow{3}{*}{ Results } & & & \multicolumn{2}{|c|}{$\mathrm{OK}$} & & \\
\hline & \multicolumn{4}{|c|}{$\mathrm{OK}$} & \multirow{2}{*}{\multicolumn{2}{|c|}{$\mathrm{OK}$}} \\
\hline & \multicolumn{4}{|c|}{$\mathrm{OK}$} & & \\
\hline
\end{tabular}

Table 2. Descriptive Statistics

\begin{tabular}{lcc}
\multicolumn{1}{c}{ Variabel } & Mean & Standard Deviation \\
\hline Convenience & 4,03 & 0,52 \\
\hline Social Needs & 4,00 & 0,53 \\
\hline Social Influence & 3,98 & 0,59 \\
\hline Dependency & 3,76 & 0,85 \\
\hline Repurchase Intention & 4,04 & 0,52 \\
\hline Technostress & 4,00 & 0,53 \\
\hline
\end{tabular}




\section{Result of Data Analysis}

Table 3. Suitability of the Model

\begin{tabular}{ccccccc}
\hline & $\begin{array}{c}\text { IFI } \\
(>0,90)\end{array}$ & $\begin{array}{c}\text { NNFI } \\
(>0,9)\end{array}$ & $\begin{array}{c}(0,08 \geq \\
\text { RMSEA } \\
\leq 0,05)\end{array}$ & $\begin{array}{c}\text { CFI } \\
(\geq 0,90)\end{array}$ & $\begin{array}{c}\text { GFI } \\
(\geq 0,90)\end{array}$ & $\begin{array}{c}\text { Goodness } \\
\text { of Fit }\end{array}$ \\
\hline $\begin{array}{c}\text { Full } \\
\text { Model }\end{array}$ & 0,94 & 0,94 & 0,042 & 0,94 & 0,81 & Good \\
\hline
\end{tabular}

Table 4. Hypotheses Testing

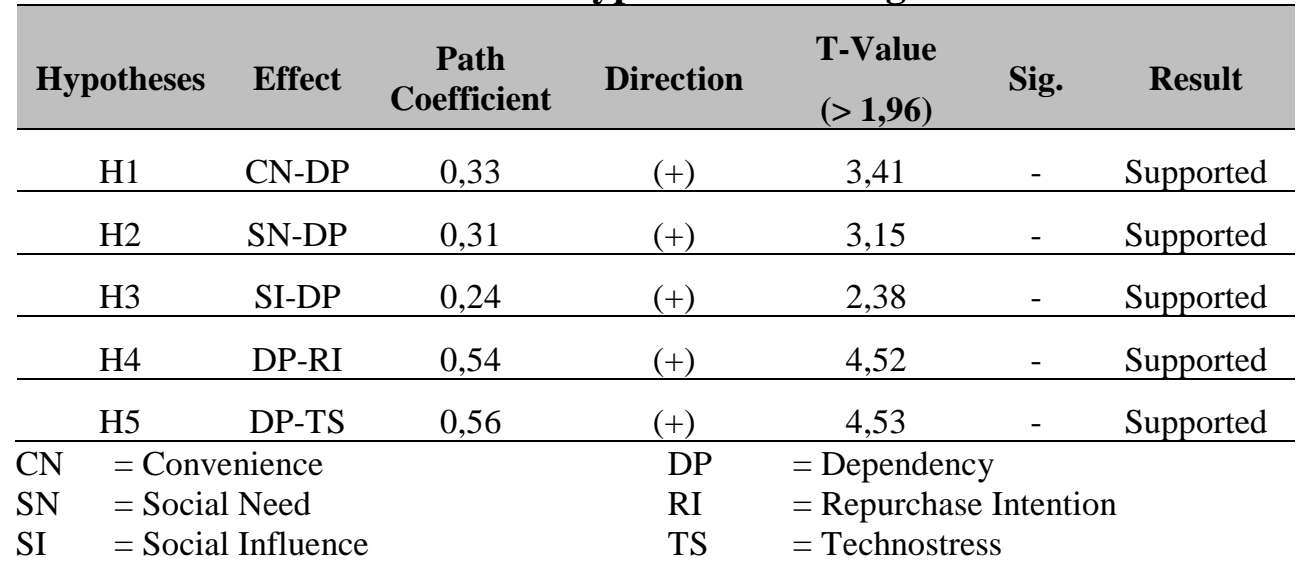

The results of data analysis in the hypothesis testing described below refer to Table 3 and 4 above. The results of the first hypotheses testing in this study indicate that the convenience of smartphone has a positive effect on consumers' dependency toward smartphone. This results support previous study by Ting et al. (2011) which states that convenience has a positive and significant effect on dependency toward smartphone. It shows that the more comfortable a person when using and after using his/her smartphone, he/she tends to depend more on his/her smartphone, which means that convenience has a positive and significant influence on dependency toward smartphone. The results of first hypotheses testing in this study also reinforces the opinion of Genova (2010) that consumers can obtain useful information easily and quickly through the internet by simply clicking a button on their smartphone, when they travel, rest at home, travel abroad, and so on, resulting in consumers becoming very dependent on their smartphone.

The results of the second hypotheses testing in this study indicate that consumers' social needs have a positive effect on consumers' dependency toward smartphone. The results of this study are in line with the results of Wei and Lo (2006) research which revealed that social needs are positively correlated to dependency toward smartphone. This means that the higher a person's social needs (consumers), the higher the dependency toward smartphone. On the other hand, if the social needs of a person (consumers) are lower, then the dependency toward smartphone is also lower. The results of testing the second hypotheses in this study also support the opinion of Lippincott (2010) which states that social needs are one of the determinants of consumers' dependency toward smartphone, because smartphone have become much more flexible, allowing consumers to increase their use to communicate and maintain relationships that occur between individuals. 
The results of the third hypotheses testing in this study indicate that social influence has a positive effect on consumers' dependency toward smartphone. This results support the study from Klobas and Clyde (2001) who found that social influences have a positive influence on dependency toward smartphone. This means that the higher the social influence of the other parties, the higher the tendency of dependency toward smartphone. Conversely, if the needs of social influence from other parties are lower, then the dependency toward smartphone tends to be lower too. The results of the testing of the third hypotheses also reinforce the opinion of Auter (2007) stating that friends and family members are seen as social influencers who are considered important for consumers in encouraging greater dependency toward smartphone. This shows that other parties who give a very strong social influence to someone until he experiences dependence on his/her smartphone, are usually people who have known their characters in depth such as close friends or even relatives such as their parents (father or mother), brother, and sister.

The results of the fourth hypotheses testing in this study indicate that consumers' dependency toward smartphone has a positive effect on consumers' repurchase intention. This result supports previous studies that conducted by Suki \& Suki (2013); Ting et al. (2011); and Vahabzadeh et. al. (2014) who have found that dependency toward smartphone has a positive and significant effect on repurchase intention. This means that the higher the dependency toward smartphone, the higher purchase intention tends to be higher and conversely the lower the dependency toward smartphone, then the intention of repeat purchase tends to be lower too.

The results of the fifth hypotheses testing in this study indicate that consumers' dependency toward smartphone has a positive effect on consumers' technostress. This result is in line with previous study that conducted by Charles, et al. (2013) who found that since smartphone are the main information technology device, people feel the need or importance to adapt to these smartphones in order to keep up with technological developments, but the excessive dependency (compulsive use) of smartphones can increase technostress. The fifth hypotheses testing results also support the statement of O'Guinn and Faber (1989) which defines compulsive behavior as a response to an uncontrollable urge or desire to get, use, or feel or activities that direct individuals to engage in repetitive actions in the end it will endanger individuals, or others. For example, the ability of smartphone capability of delivering fast feedback originating from social networks and communication causes users to check their smartphones more often. Repeated checks on smartphone are considered compulsive behavior (Oulasvirta et al., 2012). Compulsive behavior/excessive dependency that can not be avoided, and can result in the emergence of adverse consequences in the form of psychological pressure such as depression and stress (Matusik \& Mickel, 2011).

\section{CONCLUSSION}

This research attempts to prove the arguments empirically, namely by testing the effect of convenience to dependency toward smartphones, the effect of social needs to dependency toward smartphones, the effect of social influence to dependency toward smartphones, the effect of dependency toward smartphones on repurchase intention, and the effect of dependency toward smartphones on technostress.

The convenience has a positive effect on dependency toward smartphones, thus the first hypotheses in this study is accepted, which means that the more comfortable using a 
smartphone, the higher their dependency toward smartphone. Furthermore, the social needs have a positive effect on dependency toward smartphones, thus the second hypotheses in this study is accepted, which means that the higher a person's social needs such as the more frequent someone interacting with other people can increase their dependency toward smartphones.

The social influence has a positive effect on dependency toward smartphones, thus the third hypotheses in this study is also accepted, so that it can be said that the higher the social influence that comes from other people and the social environment around a person can make higher dependency toward smartphones. Likewise, the dependency toward smartphones has a positive effect on repurchase intention, thus the fourth hypothesis in this study is accepted, which means that a person has more dependency toward smartphones, the higher the intention to repurchase a smartphone in the future. In addition to this result, the dependency toward smartphones has a positive effect on technostress, thus the fifth hypotheses in this study is accepted too, so that the higher the dependency toward smartphones, the higher the technostress will be experienced.

Empirically proven research results indicate that a person's dependency toward smartphones is triggered by the convenience of using smartphones, the demand to meet social needs, the presence of social influence from the surrounding environment, which in turn triggers increased dependency toward smartphones. In addition, there is a positive impact caused by dependency toward smartphones is the intention to buy more in the future. This research provides an opportunity for smartphone producers and marketers to get as many new consumers as possible and potential consumers of smartphone by utilizing the factors that cause dependency, while on the other hand the negative impact is often felt by someone due to excessive dependency toward smartphone can result on the emergence of adverse consequences in the form of technostress, as well as psychological pressure such as depression and stress.

Although this research argument is empirically supported, it still has some limitations. The first limitation relates to time. This research was carried out only at one time because of the limited resources of the researchers. While dependency toward smartphones accumulates along with the frequent interaction with smartphones. The second limitation is related to objects and research samples. Related to the object of the research, the brands studied in this study are limited to global brands in the smartphone industry. The third limitation is the research context is limited to dependency behavior on smartphone, which is reviewed based on the domain of communication science using the approach of media dependency theory. The fourth limitation is the context of technostress in this study is limited to smartphone, and the fifth limitation is the techostress theory approach is only viewed from the aspect of clinical psychology.

\section{REFERENCES}

Alcañiz, E.B., Mafe', C. R., Manzano, J.A., \& Blass, S.S. (2008). Influence of online shopping information dependency and innovativeness on internet shopping adoption. Online Information Review, Vol. 32 No. 5, pp. 648-667.

Auter, P.J. (2007). Portable social groups: willingness to communicate, interpersonal communication gratifications, and cell phone use among young adults. International Journal Mobile Communications, Vol. 5 No. 2, pp. 139-56. 
Ayyagari, R., Grover, V., \& Purvis, R. (2011). Technostress: Technological Antece-dents and Implications. MIS Quarterly, 35 No.4, pp.1-10.

Ball-Rokeach, S.J. (1985). The Origins of Individual Media-System Dependency Theory: A Sociological Framework. Communication Research, Vol. 12 Issue 4, 1985.

Ball-Rokeach, S.J. \& Defleur, M. (1989). Theories of Mass Communication. New York: Logman.

Ball-Rokeach, S.J. (1998). A Theory of Media Power and a Theory of Media Use: Different Stories, Questions, and Ways of Thinking. Mass Communication and Society, Vol.1 No.1-2, pp.5-40.

Backer, Elisa. (2010). Using Smartphone and Facebook in A Major Assessment: The Student Experience. E-Journal. Australia: University of Ballarat.

Charles, S. T., Piazza, J. R., Mogle, J., Sliwinski, M. J., \& Alemida, D. M. (2013). “The wear and tear of daily stressors on mental health. Psychological Science, Vol. 24 No. 5, pp. 733-741.

Davis, F.D., Bagozzi, R.P., \& Warshaw, P.R. (1989). User Acceptance of Computer Technology: A Comparison of Two Theoretical Models. Management Science, Vol. 35, No.8, pp. 982-1002.

Genova, G.L. (2010). The anywhere office $=$ anywhere liability. Business Communication Quarterly, Vol. 73, pp. 119-26.

Grant, A.E., Guthrie, K.K., \& Ball-Rokeach, S.J. (1991). Television shopping: a media system dependency perspective. Communication Research, Vol. 18 No. 6, pp. 77398.

Griffiths, M. (1998). Does Internet and Computer 'Addiction' Exist?: Some Case Study Evidence. Available at: http://www.intute.ac.uk/socialsciences/archive/iriss/papers /paper47.htm. Accessed on December 2015.

Hahn, J. (2010). Information seeking with Wikipedia on Ipod Touch. Reference Service Rewiew, 38(2), 284-298.

Hair J.R, Josep, F., Black, W.C., Babin, B.J., \& Anderson, R.E. (2010). Multivariate Data Analysis. Seventh Edition. New Jersey: Pearson Prentice-Hall, Inc.

Hovart, A.T. (1989). Coping with addiction. Available at: http://www.cts.com/babt smrt/coping/html. Accessed on December 2015.

Hudson, A. (2010). Measuring the impact of cultural diversity on desired mobile reference services. Reference Research Review, Vol. 38 No. 2, pp. 1-13.

Keaveney, S.M. \& Parthasarathy, M. (2001), Customer switching behaviour in online services: An exploratory study of the role of selected attitudinal, behavioural, and demographic factors. Journal of the Academy of Marketing Science, Vol. 29 No. 4, pp. $374-90$.

Klobas, J.E. \& Clyde, L.A. (2001). Social influence and internet use. Library Management, Vol. 22 No. 1, pp. 61-7. 
Lee, Y.K., Chun, T.C., You, L., \& Zhao, H.C. (2014). The dark side of smartphone usage: Psychological traits, compulsive behavior and technostress. Computers in Human Behavior, Vol.31, pp. 373-383.

Lippincott, J.K. (2010). A mobile future for academic libraries. Reference Services Review, Vol. 38 No. 2, pp. 1-20.

Loges, W.E. (1994). Canaries in the coal mine: Perception of threat and media system dependency relations. Communication Research, Vol. 21 No.1, pp. 5-23.

Mafe, C.R. \& Blas, S.S. (2006). Explaining Internet dependency. Internet Research, Vol. 16 No. 4, pp. 380-97.

Mayasari, I. (2010). Mencermati Perilaku Smarthphone Niacs. Marketing, Edisi Minggu. Bisnis Indonesia, pp.13.

Mason, W.A., Conrey, F.D., \& Smith, E.R. (2007). Situating social influence processes: Dynamic, multidirectional flows of influence within social networks. Personality and Social Psychology Review, Vol. 11, pp. 279-300.

Matusik, S.F. \& Mickel, A.E. (2011). Embracing or Embattled by Converged Mobile Devices? Users' Experiences with A Contemporary Connectivity Technology. Human Relations, Vol. 64 Issue 8.

Millward, S. (2014). Indonesia Diproyeksi Lampaui 100 Juta Pengguna Smartphone di 2018 Keempat di Dunia. Available at: https://id.techinasia.com/jumlah-penggunasmartphone-di-indonesia-2018. Accessed on Decem-ber 2015.

O’Guinn, T.C. \& Faber, R.J. (1989). Compulsive Buying: A Phenomenological Exploration. Journal of Consumer Research, Vol. 16, pp. 147-157.

Oliver, R.L. (1999). Whence consumer loyalty. Journal of Marketing, Vol. 63, No. 4, pp. 33-44.

Oulasvirta, A., Rattenbury, T., Ma, L., \& Raita, E. (2012). Habits make smartphone use more pervasive. Personal and Ubiquitous Computing, Vol. 16(1): 105-114.

Patwardhan, P. \& Yang, J. (2003). Internet dependency relations and online consumer behaviour: A media system dependency theory perspective on why people shop, chat, and read news online. Journal of Interactive Advertising, Vol. 3 No. 2, pp. 121.

Raskin, R. (2006). Facebook faces its future. Young Consumers, Vol. 4 No. 1, pp. 56-8.

Rice-Lincoln, S. (2011). 2012 Promises to Be the Year of Mobile Marketing. Available at: http://masterthenewnet.com/2012-promises-to-be-the-year-of-mobile-marketing. Accessed on December 2015.

Schiffman L.G., Kanuk, L.L., \& Wisenbut, J. (2009). Consumer Behavior. $10^{\text {th }}$ ed. New Jersey: Pearson.

Shu, Q., Tu, Q., \& Wang, K. (2008). Technostress under different organizational environments: An empirical investigation. Computers in Human Behavior, 24(6), pp. 3002-3013. 
Stephen, K.K. \& Davis, J. (2009). The social influences on electronic multitasking in organization meetings. Management Communication Quarterly, Vol. 23 No. 1, pp. 63-83.

Suki, N.M. \& Suki, N.M. (2013). Dependency on Smartphones: An Analysis of Structural Equation Modelling. Jurnal Teknologi (Social Sciences), 62(1), pp. 49-55.

Thamrin, S.D. (2003). Studi Mengenai Proses Adopsi Konsumen Pasca Masa Tayang Iklan Produk Xon-Ce di Surabaya. Jurnal Sains Pemasaran Indonesia, Vol. 2 No 2: 141-154.

Tian, L., Shi, J., \& Yang, Z. (2009). Why does half the world's population have a mobile phone? An examiniation of consumers' attitudes toward mobile phones. Cyber Pshycohology and Behaviour, Vol. 12 No. 5, pp. 513-516.

Tikkanen, I. (2009). Maslow's hierarchy and pupils' suggestions for developing school meals. Nutrition and Food Science, Vol. 39 No. 5, pp. 534-543.

Ting, D.H., Lim, S.F., Patanmacia, T., Low, C.G., \& Gay, C.K. (2011). Dependency on smartphone and the impact on purchase behavior. Young Consumers, Vol. 12 No. 3, pp. 193-203.

Vahabzadeh, S., Duneghe, S.S., Khachoei, T.A. (2014). A Study of the Factors Influencing Dependency and Its Effect on the Purchase Behavior of the Iranian Consumers of Smartphones. Switzerland Research Park Journal, Vol. 103 No.2, pp. $1120-1132$.

Wei, R. \& Lo, V.H. (2006). Staying connected while on move: Cell phone use and social connectedness. New Media Society, Vol. 8 No. 1, pp. 53-72.

Wulandari, R. (2015). Hubungan Antara Kontrol Diri dengan Kecanduan Game Online pada Remaja di Warnet Lorong Cempaka Dalam Kelurahan 26 Ilir Palembang. Jurnal Fakultas Psikologi Universitas Bina Dharma Palembang. 